\title{
Więzienie w Kielcach w czasie powstania styczniowego
}

The prison in Kielce during the January uprising

\section{STRESZCZENIE:}

W czasie powstania styczniowego na terenie Kielecczyzny toczyły się zacięte walki. W związku z tym więzienie w Kielcach z prowincjonalnego zakładu karnego w mieście powiatowym stało się jednym z ważniejszych miejsc odosobnienia w Królestwie Polskim. Koncentrowano w nim więźniów z całej południowej części guberni radomskiej. Tekst niniejszy jest próbą przedstawienia - w oparciu o dokumenty archiwalne i relacje więźniów - warunków panujących w tym czasie w kieleckim więzieniu i wpływu, jaki na los więźniów miały osoby nadzorujące ich pobyt w więzieniu, zwłaszcza naczelnik wojenny generał Onufry Czengery.

Słowa kluczowe: Kielce, więzienie, powstanie styczniowe, Królestwo Polskie

Tereny Kielecczyzny w czasie powstania styczniowego stały się obszarem, na którym intensywność walk należała do największych w skali całego objętego powstaniem terytorium. Operowały tu oddziały Mariana Langiewicza, Dionizego Czachowskiego, Zygmunta Chmieleńskiego czy Józefa Hauke-Bosaka. Od pierwszego dnia insurekcji toczyły się tu z różnym natężeniem - intensywne walki. Tutaj też najdłużej, bo aż do lutego 1864 r., operowały duże oddziały powstańcze. Było to możliwe zarówno dzięki patriotycznej postawie mieszkańców, jak i bliskości Galicji, z której powstanie otrzymywało wszechstronne wsparcie. Jak w całym kraju, rezultaty walk były tu zazwyczaj niepomyślne dla powstania. Porażki z rzadka przeplatane były zwycięstwami. Nie miejsce tu oczywiście na na- 
wet pobieżny opis tych wydarzeń, tym bardziej, że literatura przedmiotu jest bardzo bogata ${ }^{1}$.

W niniejszym tekście chciałbym przedstawić sytuację, jaka panowała $\mathrm{w}$ czasie powstania $\mathrm{w}$ kieleckim więzieniu. Ten niewielki, prowincjonalny zakład karny stał się nagle jednym z ważniejszych w Królestwie Polskim. Przez jego mury przewinęło się kilka tysięcy osób podejrzewanych o przestępstwa polityczne. Dla większości z nich pobyt w kieleckim więzieniu stanowił jedynie krótki epizod na powstańczo-zesłańczym szlaku, dla innych - miejsce, w którym spędzili wiele miesięcy pełnych obawy o własne życie i losy rodzin.

W kieleckim archiwum zachowało się bardzo mało dokumentów, w których możemy znaleźć informacje o tym, co działo się w tutejszym więzieniu w czasie powstania. Nieliczne informacje na ten temat znaleźć możemy jedynie w ogólnie słabo zachowanych aktach kieleckiego naczelnika wojennego. W tej sytuacji najcenniejszych informacji o położeniu w kieleckim więzieniu dostarczają niewątpliwie relacje osób w nim przetrzymywanych. Szczęśliwie takich przekazów mamy aż pięć, przy czym ich autorzy trafili tam w różnych okolicznościach, w różnym czasie i pod różnymi zarzutami. Najbardziej obszerne relacje pozostawili Józef Ożegalski i Bolesław Anc, którzy w więzieniu kieleckim przebywali najdłużej. Zdecydowanie krótsze - co nie znaczy, że mniej interesujące - są relacje Ludomira Grzybowskiego, Jana Siwińskiego i Kornela Zielonki. Wspomnienia innych powstańców pozwalają zaś porównać sytuację w kieleckim więzieniu z innymi zakładami, w których przetrzymywano powstańców i osoby podejrzewane o udział w styczniowej insurekcji.

Przedpowstaniowa historia więzienia w Kielcach jest dość krótka. W związku z tym, że aż do końca XVIII w. Kielce nie pełniły żadnej poważniejszej roli administracyjnej, nie było potrzeby lokalizacji tam placówki penitencjarnej. Dopiero w roku 1809, po włączeniu miasta do Księstwa Warszawskiego, w Kielcach zlokalizowano sąd, przy którym powstał naprędce zorganizowany areszt. Mieścił się on w prowizorycznie zaadaptowanych na ten cel budynkach, zlokalizowanych w kompleksie zabudowań kieleckiego Wzgórza Zamkowego, powstałych kilkadziesiąt lat wcześniej z przeznaczeniem na stajnie i wozownie biskupów krakowskich $^{2}$.

${ }^{1}$ Literatura przedmiotu jest tu bardzo bogata. Najpełniejszy dotąd pełny opis przebiegu powstania styczniowego na Kielecczyźnie: W. Caban, Z dziejów powstania styczniowego w rejonie Gór Świętokrzyskich, Warszawa-Kraków 1989.

${ }^{2}$ Ł. Stefański, Więzienie w Kielcach w latach 1826-1918, Kielce 2010 (na prawach rękopisu), s. 58. 
W roku 1816, po podjęciu ostatecznej decyzji o zlokalizowaniu w Kielcach stolicy województwa krakowskiego, zdecydowano również o zorganizowaniu $\mathrm{w}$ mieście sądu kryminalnego wraz z więzieniem. Ponieważ jednak w Kielcach nie było budynku, który w krótkim czasie można by zaadaptować na więzienie, więźniów i aresztantów początkowo przetrzymywano w oddalonych o kilkanaście kilometrów Chęcinach. Było to jednak rozwiązanie dość kłopotliwe, zwłaszcza w przypadku aresztantów. Szybko rozpoczęto więc kompleksową przebudowę na potrzeby więzienia gmachów dawnych stajni i wozowni biskupich. Zbudowano kilka dodatkowych budynków oraz część muru okalającego obiekt. Całość pokryto nowym gontem, założono w oknach kraty, a także wstawiono ciężkie dębowe drzwi z wizjerami. Wszystko to trwało bardzo długo i więzienie w Kielcach - jeżeli można tak powiedzieć - otworzyło swoje podwoje dopiero w roku 1826, jako Dom Kary i Poprawy w mieście Kielcach (w dokumentach występuje także nazwa Więzienie Zamek Kielecki) ${ }^{3}$.

W przeciwieństwie do wielu obiektów penitencjarnych mieszczących się $\mathrm{w}$ budynkach poklasztornych, które stosunkowo łatwo można było przerobić na więzienia, w Kielcach nie było to możliwe. W ramach adaptacji nie zdecydowano się na gruntowną przebudowę wnętrza. W związku z tym cele więzienne, jeżeli chodzi o ich rozmiar i pojemność, były bardzo zróżnicowane. Najwięcej miejsc było w wieloosobowych celach, zwanych przez więźniów kaźniami. Mogły one pomieścić od kilkunastu do nawet ponad 30 osadzonych. W dolnej części obiektu urządzono kilka jednoosobowych cel. Niektóre z nich nie posiadały okien i pełniły funkcję karcerów. Po rozbudowie kompleks więzienny składał się z kilku otoczonych kamiennym murem budynków, rozlokowanych wokół dwóch dziedzińców. Przy jednym znajdowała się większość zabudowań administracyjnych, pralnia, a także budynek w którym urządzono cele przeznaczone dla kobiet. Drugi z nich, z okrąłym klombem na środku, z trzech stron otaczał budynek dawnych wozowni biskupich, mieszczący oddział męski więzienia i szpital ${ }^{4}$.

Co zmieniło się w kieleckim więzieniu po wybuchu powstania styczniowego? Przede wszystkim większość więźniów kryminalnych odesłano pod eskortą do więzienia w Chęcinach. Następnie posiadający dwa dziedzińce kompleks więzienny podzielono na dwie części. W mniejszej części umieszczono więźniów kryminalnych, większą „zarezerwowano” dla politycznych. Obie grupy nie miały ze sobą praktycznie kontaktu, poza tym, że więźniowie kryminalni wykonywali wszystkie prace na terenie

${ }^{3}$ Ibidem.

${ }^{4}$ Ibidem, s. 58-59. 
więzienia, łącznie z usuwaniem kubłów, w które załatwiano potrzeby fizjologiczne ${ }^{5}$. Dało się również zauważyć różnicę w traktowaniu przez strażników obu grup więźniów ${ }^{6}$.

Warto w tym miejscu poświęcić kilka słów osobom, które miały bezpośredni wpływ na to, jak przebiegał więźniom politycznym czas spędzony w kieleckim więzieniu. Zacznijmy od osób mających z nimi codzienny bezpośredni kontakt, a więc strażników. Przed powstaniem styczniowym całość personelu kieleckiego więzienia stanowili Polacy. W materiale źródłowym brak informacji o tym, aby po wybuchu insurekcji zaszły w tym zakresie jakieś poważniejsze zmiany. Widocznie postawa strażników nie dała władzom pretekstu do ich wymiany. Niemniej nadzór nad osadzonymi został wzmocniony, bowiem teren wokół więzienia patrolowali żołnierze rosyjscy. Czy wynikało to z ograniczonego zaufania do polskich strażników, czy też miało zapobiegać kontaktom więźniów ze światem zewnętrznym i ewentualnym ucieczkom? Trudno rozstrzygnąć.

Na terenie więzienia pilnowało więźniów kilkunastu strażników. Według informacji z marca 1864 r. było ich 12 - jeden I klasy (starszy), dwóch II klasy i dziewięciu III klasy (młodszych). Rekrutowali się oni z mieszkańców podkieleckich wsi, którzy mieli za sobą służbę w wojsku carskim ${ }^{7}$.

Przed powstaniem styczniowym zatrudnianie w charakterze strażników więziennych byłych żołnierzy armii rosyjskiej było powszechną praktyką. Trzeba przyznać, że przedstawiciele tej grupy - o ile cieszyli się dobrym zdrowiem - byli dobrymi kandydatami na te stanowiska. Po spędzeniu przynajmniej kilkunastu lat w szeregach armii rosyjskiej byli przyzwyczajeni do karności i ślepego wykonywania poleceń zwierzchników, umieli posługiwać się bronia, znali też język rosyjski, choć ta ostatnia umiejętność nie miała aż takiego znaczenia. Wieloletnia rozłąka z rodzinnymi stronami sprawiała dodatkowo, że byli żołnierze, chociaż „tutejsi”, nie mieli z lokalnym środowiskiem silnych powiązań rodzinno-towarzyskich. Ogólnie byli oni postrzegani jako osoby oddane władzom carskim $\mathrm{i}$ ich postawa $\mathrm{w}$ czasie powstania to potwierdziła ${ }^{8}$. $\mathrm{Z}$ drugiej strony taka sytuacja była dla więźniów o tyle komfortowa, że nie było mowy o problemach z nawiązaniem kontaktu ze strażnikami, spowodowanych barierą językową. W zachowanych relacjach więźniów kieleckiego więzienia brak jakichkolwiek skarg na ich postawę.

${ }^{5}$ Władysław Zapałowski wspomina, że w więzieniu w Radomiu czynności te wykonywali sami więźniowie polityczni. W. Zapałowski, Pamiętniki Władysława Zapałowskiego (Płomienia) z roku 1863-1870, z przedm. K. Bartoszewicza, Wilno 1913, t. 1, s. 25.

${ }^{6}$ J. I. Ożegalski, Wspomnienia krwawych czasów 1863, Brzesko 2006, s. 139.

${ }^{7}$ Ł. Stefański, op. cit., s. 74-75.

${ }^{8}$ Por. W. Caban, Stużba rekrutów z Królestwa Polskiego w armii carskiej w latach 1832-1873, Warszawa 2001, s. 197-201. 
Do kadrowych pracowników więzienia zaliczano również - oprócz naczelnika - lekarza, felczera, pisarza i kapelana. W czasie powstania styczniowego naczelnikiem więzienia był Antoni Łukasiewicz, pisarzem - Mikołaj Paszyc, lekarzem - Władysław Drażdżyński, felczerem - Jan Czechowski, zaś kapelanem - ks. Adam Englisz. Wszyscy zachowywali się lojalnie wobec władz ${ }^{9} \mathrm{i}$ starannie wypełniali swoje obowiązki, a jednocześnie współczuli więźniom i starali się im pomagać. O każdej z tych osób posiadamy dość szczegółowe informacje, ale podawanie ich $\mathrm{w}$ tym wypadku nie wydaje się konieczne, gdyż $\mathrm{w}$ istocie o tym, co działo się w kieleckim więzieniu w czasie powstania styczniowego, decydował ktoś inny.

Specyfika działań przeciwko powstańcom sprawiała, iż w czasie powstania dowódcy rozsianych po Królestwie Polskim garnizonów rosyjskich uzyskali nagle zakres samodzielności i władzy niespotykany nie tylko w czasie pokoju, ale również $\mathrm{w}$ warunkach regularnej wojny. Dowodzący kilkoma rotami (kompaniami) piechoty oficer w stopniu majora czy pułkownika w sytuacji utrudnionej łączności ze zwierzchnikami, zwłaszcza w rejonach oddalonych od stolic guberni, posiadał często prawie dyktatorską władzę, którą dzielił się jedynie z dowódcami oddziałów powstańczych. W przypadku wojennych naczelników powiatów ów zakres uprawnień został dodatkowo prawnie usankcjonowany. Otrzymali oni $\mathrm{m}$. in. prawo do skazywania na śmierć każdego schwytanego $\mathrm{z}$ bronią w ręku powstańca bez konsultacji z przełożonymi ${ }^{10}$. W warunkach stanu wojennego ich władzy faktycznie podlegały również wszystkie instytucje cywilne, a więc także więzienia. Nic więc dziwnego, że czasami określano ich mianem kacyków moskiewskich ${ }^{11}$. W południowej części guberni radomskiej takim „kacykiem” był pułkownik, a później generał Onufry (Ksawery) Osipowicz Czengery ${ }^{12}$.

${ }^{9}$ Ł. Stefański, op. cit., s. 67, 79, 82, 86, 88. W tym wypadku stwierdzenie to oznacza, że nikogo $\mathrm{z}$ nich władze rosyjskie nie podejrzewały o współpracę z powstańcami, nic również nie wiadomo o takowej z innych źródeł.

${ }^{10}$ M. Berg, Zapiski o polskich spiskach i powstaniach, cz. VI, Warszawa 1906, s. 92.

${ }^{11}$ B. i J. Anc, Z lat nadziei $i$ walki 1861-1864, Brody 1907, s. 72.

${ }^{12} \mathrm{Z}$ dokumentów wynika jednoznacznie, że podczas chrztu otrzymał on imię Onufry. Także jego dzieci po ojcu pisano: Onufriewicz i Onufriewna. Mimo to w większości oficjalnych wydawnictw występuje on jako Ksawery. Jako Ксаверий Осипович Ченгеры występuje on również w rosyjskim słowniku biograficznym. Co więcej, po jego śmierci jego własna żona przedstawiała się jako „wdowa po generale Ksawerym Czengery”. Widocznie więc na co dzień swego chrzestnego imienia z jakichś powodów nie używał. Рor. Российский Государственный Военно-Исторический Архив (РГВИА), fond 400, opis 12, dieło. 7798, k. 1; В. П. Максутов, История 25-го пехотного Смоленского полка за два века его существования (1700-1900), С.-Петербург 1901, s. 1039; Русский Биографический Словарь, t. 22, С.-Петербург 1905, s. 148-149. 
Wypada bliżej przyjrzeć się owej postaci. Ten pozostający w służbie rosyjskiej syn Węgra i Polki (bardzo dobrze mówił po polsku), jako dowódca (od 1860 r.) stacjonującego w południowej części guberni radomskiej Smoleńskiego Pułku Piechoty, najpierw był naczelnikiem wojennym powiatu kieleckiego (formalnie podlegał mu również powiat stopnicki), a potem powiatów kieleckiego, opatowskiego i sandomierskiego ${ }^{13}$.

Czengery, głównie dzięki prasie zakordonowej, przede wszystkim galicyjskiej, zyskał ponurą sławę okrutnika, jednego z najgorszych moskiewskich satrapów, mordercy i rabusia ${ }^{14}$. Jeszcze kilkadziesiąt lat po upadku powstania styczniowego, na początku XX wieku, Bolesław Anc pisał: Niema zapewne nikogo w Polsce całej, z ludzi starszych $i$ inteligentnych, którzy pamiętaja wypadki powstania 1863 i 64 roku, ani z młodszego pokolenia. zajmujacego się choć trochę przeszłościa narodu, ktoby nie styszał o Czengerym, dzikim satrapie moskiewskim ${ }^{15}$. Zapewne tak było, ale wiedza ta stanowiła swego rodzaju zlepek wspomnień, relacji prasowych, a często zwykłych plotek i legend.

W jednym z krążących po Królestwie pism ulotnych pisano, iż trzeba go sprzątnać, choćby przyszło stracić tylko na to tysiac ludzi i sto tysięcy rubli ${ }^{16}$. Czengery miał być z tego bardzo zadowolony. Józef Ożegalski wspomina, że gdy jego matka chodziła do niego prosić o uwolnienie syna, zawsze wcześniej pytała pisarzy w kancelarii, w jakim generał jest humorze. Raz usłyszała, że w znakomitym, bo wyczytał w galicyjskich gazetach dużo na siebie złych rzeczy. Widocznie zła opinia w polskich pismach służyła mu wobec rzadu za pochwałe i odznaczenie ${ }^{17}$. Rzeczywiście, może dlatego, że przed powstaniem podejrzewano go o propolskie sympatie, w czasie jego trwania czynił wszystko, aby te podejrzenia od siebie oddalić. Skuteczne działania przeciwko powstańcom przyniosły mu awans generalski, ordery i niewątpliwie przyspieszyły karierę. Już w marcu 1863 r., po udanej kampanii przeciwko oddziałom Mariana Langiewicza, uzyskał nominację generalską.

W tej sytuacji dziwne może wydawać się, że dużo lepszą opinię wystawili mu ci, którzy mieli okazję zetknąć się z nim jako więźniowie kieleckiego więzienia. Czengery, jeżeli tylko nie przebywał poza miastem, żywo

${ }^{13}$ В. П. Максутов, ор.cit., s. 1041.

14 „Nadwiślanin” 1863, nr 86; 1864, nr 13; [Ignis], Święcone przed pót wiekiem (opowiadanie byłego żotnierza), „Gazeta Częstochowska” 1910, nr 83, s. 5; Z. Janeczek, Terror i przemoc w relacjach śląskiej prasy na przykładzie polskiego powstania 1863 roku, „Siemianowicki Rocznik Muzealny" 2010, nr 9, s. 20.

${ }^{15}$ B. i J. Anc, op. cit., s. 47.

16 В. П. Максутов, op.cit, s. 954.

17 J. I. Ożegalski, op.cit., s. 146. 
interesował się tym, co dzieje się w kieleckim więzieniu. Odwiedzał je często, czasami kilka razy w tygodniu. Podczas tych wizyt nie szczędził więźniom politycznym kpin i gróźb. Prawie każdy usłyszał od niego obietnicę, że zostanie rychło powieszony ${ }^{18}$. Ale niemal zawsze kończyło się na groźbach. Chociaż - jak już wspomniano - Czengery miał prawo skazywać na śmierć schwytanych powstańców i wykonywać wyroki bez konsultacji ze zwierzchnikami, to z możliwości tej praktycznie nie korzystał.

Jedyny wydany przez niego i wykonany w kieleckim więzieniu wyrok śmierci dotyczył żołnierza z oddziału Dionizego Czachowskiego - Józefa Guzowskiego ${ }^{19}$, oskarżonego o wieszanie jeńców rosyjskich po bitwie pod Stefankowem. Czengery wydał na niego wyrok śmierci, ale jednocześnie napisał do zwierzchników prośbę o ułaskawienie. Gdy została odrzucona i Guzowskiego powieszono, stała się rzecz - jeżeli wierzyć J. Ożegalskiemu - niezwykła. Na trzeci dzień po wykonaniu wyroku śmierci na Guzowskim - wspomina Ożegalski - przyszedt do nas Czengery [...], był łagodniejszym i mówit do nas: "Nie myślcie żem ja pragną śmierci Guzowskiego, wszystko robiłem co mogłem, aby dla niego uzyskać ułaskawienie, pisałem do Radomia i Warszawy, ale mi odmówiono z powodu tego, że Guzowski stużył pod Czachowskim" 20 .

Śmierć jednego powstańca oznaczała jednak prawdopodobnie wolność dla wielu innych, bo - jak dalej wspomina Ożegalski - po wizycie u więźniów generał kazał zwolnić osiemnastu z nich i to tych najciężej obwinionych. Uwolniony został nawet podejrzewany o przynależność do „żandarmerii wieszającej”, co było chyba najcięższym z możliwych zarzutów. Wyglądało to następująco: Gdy go zobaczyt, krzykną na niego: Ty hardy buntowniku, to tu jeszcze jesteś! Zawołał klucznika, a dawszy mu dwa złote powiedział: "Masz tu na piwo, a obij mi dobrze tego zuchwalca i wypędź za brame więzienna, niech ja go tu więcej nie widze na moje oczy!"21. Kiedy jeden z towarzyszących mu oficerów, zresztą Polak ${ }^{22}$, zauważył, że to jest jeden z najciężej obwinionych, Czengery miał go zgromić okrzykiem małczat, i wydał dyspozycję uwolnienia kolejnych więźniów ${ }^{23}$. Co ciekawe, polecenie „obicia” więźnia wydał nie towarzyszącym mu kozakom, ale strażnikowi więziennemu, Polakowi i weteranowi powstania listopadowego.

${ }^{18} \mathrm{~K}$. Zielonka, Wspomnienia z powstania 1863 roku i życia na wygnaniu w Syberyi, Lwów 1913, s. 24.

${ }^{19}$ Bolesław Anc pisze, że powstaniec ów nazywał się Kuźmiński. B. i J. Anc, op. cit., s. 52.

${ }^{20}$ J. I. Ożegalski, op. cit., s. 145.

${ }^{21}$ Ibidem.

${ }^{22}$ Oficer ów nazywał się Malinowski. J. Ożegalski pisze o nim: Polak, ale dziesięć razy gorszy od Moskali. Ibidem, s. 143.

${ }^{23}$ Ibidem, s. 145. 
Strażnik ów sam zauważył: Pan generał kazał mi obić tego pana, a przecież dobrze wie, że ja nikogo nie bije, bom nie od tego, gdybym to miat robić, wolałbym iść na żebry niż tu stu̇̇yć? ${ }^{24}$.

Wolność zawdzięczało mu wielu innych więźniów. Nie brakuje informacji, że w licznych wypadkach stały za tym grube łapówki. Niejeden aresztowany za uwolnienie musiał zapłacić kilkaset, a czasami nawet kilka tysięcy rubli. W tych swoistych transakcjach pośredniczyły różne osoby, do których generał miał zaufanie, jak na przykład Herman Hiller, Józef Jelski, czy ks. Paweł Gnutkiewicz, także chęciński kupiec Eisenberg. Ten ostatni był na tyle sprytny, że cieszył się zaufaniem zarówno Czengerego, jak i Organizacji Narodowej ${ }^{25}$.

Ale przecież nie zawsze. Jan Siwiński wspominał: On to pod rozmaitymi pretekstami starat się niejednego uwolnić; uwalniał na przykład młodzież, ewentualnie lat czternaście mająca, choć niejeden miat daleko więcejej.

W tej sytuacji - co może zabrzmieć dziwnie - przekraczając bramę kieleckiego więzienia niejeden pojmany powstaniec odczuwał pewną ulgę. Dlaczego? Otóż w czasie walk często zdarzało się, że żołnierze rosyjscy dobijali rannych lub mordowali jeńców, czasami tylko dlatego, że chcieli sobie przywłaszczyć ich buty ${ }^{27}$. W więzieniu takie przypadki się nie zdarzały.

Kto trafiał do więzień? W czasie powstania styczniowego w kieleckim więzieniu przetrzymywano zarówno więźniów kryminalnych, jak i politycznych. O ile jednak w tej pierwszej grupie absolutną większość stanowiły osoby odbywające karę pozbawienia wolności, to w przypadku oskarżonych o przestępstwa polityczne więzienie kieleckie było raczej aresztem śledczym niż zakładem karnym.

W zachowanych w aktach więzienia spisach więźniów brak wyszczególnienia rodzaju przestępstwa, o jakie byli podejrzewani. Część przetrzymywanych stanowili powstańcy wzięci do niewoli w czasie bitew i potyczek lub schwytani przez żołnierzy rosyjskich. Niekiedy po jakiejś poważniejszej porażce przyprowadzano ich do Kielc kilkudziesięciu, a nawet ponad stu. Jednak ci zazwyczaj byli przetrzymywani w Kielcach bardzo krótko. Z relacji więźniów możemy dowiedzieć się, że osoby których wina - w ocenie władz rosyjskich - była ewidentna, już po kilku dniach wysyłano do Radomia, gdzie niektórzy byli sądzeni i traceni, a pozostali po zakończeniu śledztwa kierowani do warszawskiej Cytadeli, skąd naj-

\footnotetext{
${ }^{24}$ Ibidem, s. 145-146.

${ }^{25}$ B. i J. Anc, op. cit., s. 72-74.

${ }^{26}$ J. Siwiński, Katorżnik czyli pamiętniki Sybiraka, Kraków 1905, s. 15.

${ }^{27}$ B. i J. Anc, op. cit., s. 61.
} 
częściej trafiali na Syberię ${ }^{28}$. Było to postępowanie zgodne z dyrektywami zwierzchników, którzy zalecali Czengeremu, aby schwytanych, co do których winy nie było wątpliwości, odsyłać do Radomia, zaś tych przeciwko którym nie było mocnych dowodów - zwalniać ${ }^{29}$.

Główną masę więźniów stanowiły osoby podejrzewane o udział w oddziałach zbrojnych, pracę $\mathrm{w}$ organizacji cywilnej lub inne formy wspierania walki zbrojnej. Zdarzały się jednak również wypadki, że w więzieniu jako więźniów politycznych zamykano osoby, które z ruchem powstańczym nie miały nic wspólnego, a osadzenie miało na celu wymuszenie łapówki za uwolnienie.

Niektórzy znaleźli się w kieleckim więzieniu przypadkiem. W kilku relacjach mamy do czynienia z informacjami, że Czengery wracając do Kielc z wypraw w teren lubił chwalić się dużą liczbą jeńców, co miało zwiększać publiczne mniemanie o skali jego wojskowych sukcesów. Oczywiście nie każda ekspedycja przeciw powstańcom kończyła się sukcesem, ale i na to był sposób. J. Ożegalski wspominał:

Wojownik z niego nie byt wielki, nie lubit się spotykać z powstańcami. Na wyprawy chodzit $z$ dużymi siłami i wielkim rozgłosem, aby wszyscy mogli się o tym dowiedzieć i zejść mu z drogi. Chodzil forsownymi marszami po dużych traktach, udajac że ściga powstańców, gdy już bardzo zmęczyt swoje wojsko, stawat w pobliżu jakiego lasu i kazat do niego strzelać z armat, udajac, że stamtad wypędza powstańców, a nareszcie kazat szturmem zdobywać las. Ofiarami takich zwycięstw najczęściej padaty baby zbierajace grzyby w lesie lub chtopi rąbiacy drzewo. Wracajac do Kielc po takiej batalii, tapat wszystkich po drogach, którzy mu tylko wpadli w ręce, dziadów, pijaków wracajacych z jarmarków, a czasem i żniwiarzy i tych w tryumfie wprowadzat do miasta, udając, że to jeńcy wojenni. Tak połapanych w kilka dni z odwachu pojedynczo wypuszczat do domu, dajac im czasem baty na pożegnanie. Wyższym wtadzom zaś raportowat, że odnióst świetne zwycięstwo, rozbiwszy w puch bandę powstańców nie straciwszy ani jednego żotnierza, za co go czekaty ordery ${ }^{30}$.

Oczywiście nadużyciem byłoby na tej podstawie stwierdzenie, że do więzienia kieleckiego trafiały same przypadkowe osoby. Jak już wspomniano, oprócz osób podejrzewanych o pomoc powstańcom, przyprowadzano tam też jeńców wziętych na polach powstańczych bitew. Ale nawet wówczas Czengery lubił robić wrażenie na mieszkańcach Kielce i okolic. Jeńców przed wejściem do miasta ustawiano w luźnej, możliwie maksy-

${ }^{28}$ Zaledwie kilka dni w więzieniu w Kielcach przebywał Jan Siwiński, wzięty do niewoli pod Komorowem w czerwcu 1863 r. Niewiele dłużej, bo około dwóch tygodni, przebywał w kieleckim więzieniu Kornel Zielonka, który do niewoli rosyjskiej dostał się po bitwie pod Jeziórkiem w końcu października 1863 r. Spośród 136 jeńców wziętych do niewoli w tej ostatniej bitwie na Syberię trafiło 125. J. Siwiński, op. cit., s. 17-18; K. Zielonka, op. cit., s. 24-38.

${ }^{29}$ Archiwum Państwowe w Kielcach (APK), Naczelnik Wojenny Powiatu Kieleckiego, sygn. 18, k. 203, 225.

${ }^{30}$ J. I. Ożegalski, op. cit., s. 146. 
malnie rozciągniętej kolumnie, aby się wydawało, że jest ich więcej niż w rzeczywistości ${ }^{31}$.

Jakie warunki panowały w kieleckim więzieniu w czasie powstania styczniowego i bezpośrednio po jego zakończeniu? W istocie nie wiadomo, na ilu więźniów przewidziana była pojemność kieleckiego więzienia $\mathrm{w}$ czasie powstania styczniowego. Być może w tym czasie nie obowiązywały jeszcze $w$ tym zakresie żadne normy. Pierwsze informacje na ten temat posiadamy dopiero $\mathrm{z}$ lat siedemdziesiątych XIX w. Określono ją wtedy na 258 osób. Warto jednak zauważyć, ze w kolejnych latach systematycznie się ona zwiększała bez powiększania powierzchni. W latach osiemdziesiątych określano ją na 290 osadzonych, zaś na przełomie XIX i XX w. - już na $320^{32}$. Nietrudno domyśleć się, że zwiększenie pojemności było możliwe dzięki zmniejszeniu powierzchni przypadającej na jednego więźnia. Zresztą pojemność tę należy uznać za "teoretyczną", gdyż niejednokrotnie zdarzało się, że rzeczywista liczba osadzonych była znacznie większa od zakładanej.

Podczas powstania $\mathrm{w}$ więzieniu kieleckim przebywało zazwyczaj około 250 więźniów, z czego ponad 80\% stanowili więźniowie politycz$\mathrm{ni}^{33}$. Oczywiście czasami dochodziło do nadzwyczajnego zagęszczenia. Tak było na przykład w końcu czerwca, gdy w bitwie pod Komorowem Rosjanie wzięli ponad 100 jeńców, których przyprowadzono do Kielc. Podobnie było na przełomie października i listopada 1863 roku, kiedy po bitwie pod Jeziórkiem do Kielc przyprowadzono ponad 130 wziętych do niewoli powstańców. Nic dziwnego, że gdy z dnia na dzień liczba osadzonych zwiększała się o prawie $50 \%$, warunki w więzieniu gwałtownie się pogarszały. Kornel Zielonka, który był w grupie jeńców przyprowadzonych do kieleckiego więzienia po bitwie pod Jeziórkiem wspominał:

Już i brama więzienna otworem stanęła $i$ weszliśmy na podwórze wysokim murem zamknięte. Dalej i kaźnia otworzyla się i nas wszystkich do niej wpakowano, a pakowano literalnie w catem znaczeniu tego wyrazu, tak, żeśmy stali jeden przy drugim - i tak wepchniętych $i$ ściśniętych zamknięto. O ułożeniu się do spoczynku nie było mowy, bo i przykucnąc się nie dało, tak ciasno staliśmy. Zdawało się, że podusimy się; już brakuje powietrza do oddychania. Okno zakratowane było wysoko, zatem podsadziliśmy jednego, aby otworzyt, lecz gdy to się nie dało, poradziliśmy, aby szybę wybit, co gdy się stało, na brzęk szkła warta larum podniosła. To nas nic nie obchodziło, gdy nam powietrza trzeba, które gdy przez wybita szybę weszło, już lżej oddychać dało. Jednakoż zawsze ciężki zaduch panowat. Tak stojąc ściśnięci w dusznem powietrzu przemęczyliśmy się do rana ${ }^{34}$.

\footnotetext{
${ }^{31}$ B. i J. Anc, op. cit., s. 68-69.

${ }^{32}$ Ł. Stefański, op. cit., s. 76-78.

${ }^{33}$ APK, Naczelnik Wojenny Powiatu Kieleckiego, sygn. 18, passim.

${ }^{34}$ K. Zielonka, op. cit, s. 24.
} 
Taka sytuacja nie dziwi, jeśli uświadomimy sobie, że ponad setkę jeńców zamknięto w jednej celi! Nawet gdyby była to ta największa, przewidziana na 36 więźniów, to i tak liczba osadzonych była trzykrotnie większa. Nic więc dziwnego, że następnego dnia rano otwierających celę strażników wydobywający się z niej fetor przyprawił o mdłości ${ }^{35}$.

Tego typu sytuacje trzeba jednak uznać za nadzwyczajne. $Z$ relacji więźniów wynika, że ogólnie warunki zakwaterowania więźniów były dużo lepsze. Warto choćby zauważyć, że osadzeni w kieleckim więzieniu wspominają jedynie o pojawianiu się różnego rodzaju insektów ${ }^{36}$, zaś Władysław Zapałowski pisze, że w Radomiu [...] ściany, podłoga i nasze wspólne łoże oblepione było różnorodnem i różnokolorowym robactwem, które zgłodniałe a żarłoczne - mimo, że miljonami ginęło, mordowane przez lokatorów, pchało się gwałtem na swych ciemięzców, i niezadawalając się krwia z ciał naszych, pakowało się w nos, uszy, a nawet w usta ${ }^{37}$.

Należy jednak w tym miejscu poczynić jedną uwagę. Otóż w przypadku więźniów politycznych - według relacji jednego z więźniów - przy rozdziale cel dyrektor więzienia dokonywał ich podziału na „inteligencję i nieinteligencję". Zachowane relacje pochodzą od osób, które zapewne zaliczone zostały do tej pierwszej grupy. Nie wiadomo więc, czy wszystkich osadzonych traktowano podobnie.

J. Ożegalski celę, w której umieszczono go razem z bratem, opisał następująco: Były to dwa duże, jasne, $i$ czysto utrzymane pokoje, z czterema oknami, dwa z nich wychodziły na park $i$ wpuszczaly świeże powietrze, drugie dwa wychodzity na podworzec, drzwi między tymi dwoma pokojami byty zawsze otwarte. [...] W kaźniach znajdywały się stoliki i krzesła, oraz łóżka z prywatna pościela, która wolno było każdemu mieć. Gdyby nie zakratowane okna, to by się nie poznało, że to więzienie ${ }^{38}$. Podobny opis zawiera relacja Bolesława Anca, który po latach wspominał: Ja z częścia mych towarzyszy dostałem się do dwóch wielkich izb, tak ze z tymi co tam już byli, było nas coś dwudziestu pięciu, a każdy miał łóżko żelazne z siennikiem, kocem $i$ stomiana poduszką ${ }^{39}$. Oczywiście nie we wszystkich celach było tak dobrze.

W podziemiach budynku znajdowało się kilka maleńkich lochów, tzw. sekretnych, pełniących funkcje karcerów. Ludomir Grzybowski, który miał nieszczęście przebywać $\mathrm{w}$ jednym $\mathrm{z}$ takich pomieszczeń, wspomi-

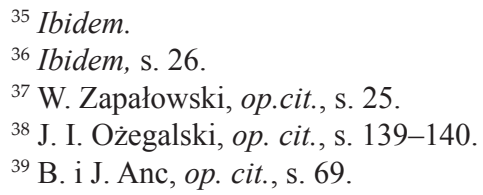


nał: [...] mnie wpakowano do jednego z takich, gdzie prawie obrócić się nie było można. Loch ciemny, wilgotny, troche słomy na ziemi i poza tym nic ${ }^{40}$.

Decyzję o zamknięciu więźnia w jednej z tych cel podejmował osobiście Czengery, a czynił to w stosunku do więźniów, którzy z jakiegoś powodu mu się narazili. Powody mogły być rozmaite, często głównym był jak się zdaje - zły humor generała. Grzybowskiego na przykład zamknięto tam z powodu jego "hardości”, której jaskrawym przejawem miało być niezdjęcie przed generałem czapki ${ }^{41}$. Po głośnych protestach przeniesiono go do innej celi, już posiadającej okna, suchej i ciepłej, bo w piecu było palone. Jednak jego osadzenie przez cały czas miało charakter zaostrzony, gdyż w przeciwieństwie do innych więźniów siedział sam, drzwi od celi nie były otwierane na dzień, nie mógł więc z nikim się spotykać, a jedzenie z kotła było jego zdaniem okropne ${ }^{42}$.

Jedyna, jeśli można było tak powiedzieć, zaletą tego stanu rzeczy był fakt, iż osadzeni w karcerach nie uczestniczyli w apelach i cotygodniowych smotrach, jakie w soboty urządzał w więzieniu Czengery. Więźniów ustawiano wówczas w szereg, a generał przechodząc przed ich frontem swoim donośnym głosem ${ }^{43}$ wymyślał więźniom od hyclów, łajdaków i złodziei, obiecując przy tym szubienicę, katorgę, baty. Na szczęście prawie zawsze kończyło się na groźbach, ale i te niejednego wpędzały w podły nastrój ${ }^{44}$.

Z zachowanych dokumentów wynika, że dzienny koszt wyżywienia jednego więźnia skalkulowany był na 16 kopiejek srebrem ${ }^{45}$. Władysław Zapałowski wspomina zaś, że w więzieniu w Radomiu było to 20 kopiejek $^{46}$. Czy więc w gubernialnym Radomiu stawki były wyższe, czy pomiędzy sierpniem 1863 r. a marcem 1864 r., kiedy do więzienia trafił Zapałowski, ogólnie zostały one podniesione? Informacji na ten temat nie udało mi się znaleźć.

$\mathrm{Na}$ śniadanie więźniowie dostawali kawałki chleba nanizane na drewniany patyczek, aby miał przepisowa wage, oraz żur, w którym - jak wspo-

${ }^{40}$ L. Grzybowski, Opis powstania polskiego w roku 1863 i 1864 w województwie krakowskim, oprac. W. Caban i Z. J. Adamczyk, Kielce 1994, s. 137.

${ }^{41}$ Ibidem, s. 136-137.

${ }^{42}$ Ibidem, s. 138.

${ }^{43} \mathrm{O}$ donośności głosu Czengerego wspomina się często. Zdaniem Ożegalskiego gdy krzyczał, to słyszało go pół miasta, Grzybowski wspomina, że jego wrzaski w więzieniu słychać było na kieleckim rynku, a więc kilkaset metrów od więzienia.

${ }^{44}$ L. Grzybowski, op. cit., s. 139.

${ }^{45}$ APK, Naczelnik Wojenny Powiatu Kieleckiego, sygn. 18, k. 177. Warto w tym miejscu podkreślić, że dokładnie tyle samo przeznaczano w tym czasie na dzienne wyżywienie żołnierza armii rosyjskiej.

${ }^{46}$ W. Zapałowski, op.cit., s. 27. 
mina J. Ożegalski - dość grubo ptywało ttustości. Na obiad dawano krupnik, grochówkę lub kapuśniak i do tego po pół funta mięsa, znowu jak chleb pospinanego kołeczkami, na kolację zaś najczęściej krupnik ze słoniną ${ }^{47}$. Jedzenie było więc dość smaczne, co więźniowie przypisywali staraniom dyrektora więzienia, który miał o to dbać osobiście. Problemem była niewątpliwie jego monotonia, ale i na to był sposób. Więźniowie mogli podjąć decyzję o tym, aby pieniądze na ich żywienie wydawano w gotówce wybranemu przez nich kucharzowi, który miał możliwość przygotowania posiłków, a także - oczywiście pod eskortą - robienia zakupów w mieście. Można się domyślać, że dla takiego klienta miejscowi kupcy obniżali ceny i więźniom niczego nie brakowało. Poza tym więźniowie, którzy mieli odpowiednie środki, mogli nawet zamawiać sobie obiady w kieleckich restauracjach.

Rozkład dnia wyglądał następująco: więźniów budzono o szóstej rano. Strażnicy otwierali wówczas drzwi do cel, które pozostawały otwarte przez następne dwanaście godzin. Więźniowie polityczni mogli w tym czasie spacerować rozmawiać, śpiewać, grać w karty, a nawet - jak wspominał J. Ożegalski - głośno i bezkarnie wymyślać moskalom ${ }^{48}$. Pisał on, że prawo takie przysługiwało $\mathrm{w}$ tym czasie w Rosji wszystkim więźniom, jako tzw. nieszczastnym (nieszczęśliwym). Więźniowie polityczni nie byli zatrudniani do żadnych prac na terenie więzienia ani poza nim. Oczywiście ów rozkład dnia nie dotyczył osadzonych w karcerach, bo ci przez cały czas przebywali w zamknięciu i izolacji.

Większym problemem nie były również kontakty ze światem zewnętrznym. Wprawdzie członkowie rodzin więźniów mogli się z nimi spotykać najwyżej raz $\mathrm{w}$ tygodniu $\mathrm{w}$ gabinecie dyrektora więzienia i w jego obecności (albo któregoś z rosyjskich oficerów), ale istniały inne sposoby. Co sobotę więzienie odwiedzały kieleckie damy, przynosząc więźniom w podarunku od mieszkańców miasta kosze z żywnością, czystą bielizną, a nawet winem i cygarami ${ }^{49}$. Zawartości tych koszy widocznie nie kontrolowano zbyt wnikliwie, bo były w nich również listy i pieniądze dla więźniów. Te ostatnie były potrzebne choćby po to, aby otworzyć kolejną drogę do kontaktu z miastem. Część okien cel wychodziła na ogólnodostępny park miejski. Chociaż wokół więzienia krążyły warty

${ }^{47}$ J. I. Ożegalski, op. cit., s. 140-141.

${ }^{48}$ Ibidem, s. 141.

${ }^{49}$ B. i J. Anc, op. cit., s. 69. W. Zapałowski wspominał, że w radomskim więzieniu aresztanci mogli robić zakupy za pośrednictwem wyznaczonych do tego żołnierzy. Formalnie jednak nie wolno było wnosić do więzienia alkoholu i tytoniu. Zakaz ów nie był jednak skuteczny: Gdy bliżej poznaliśmy się z naszymi posługaczami - pisał Zapałowski - mieliśmy wszystko, i wódkę i papierosy, ale cztery razy więcej to nas kosztowało. W. Zapałowski, op.cit., s. 27. 
złożone z żołnierzy rosyjskich, ale i na to był sposób. Wystarczyło przez okno wyrzucić srebrnego rubla, a żołnierze wiedzieli już, że powinni odejść za węgieł murów i nie zjawiać się przez kilkanaście następnych minut ${ }^{50}$. W tym czasie można było swobodnie rozmawiać z osobami stojącymi pod oknami cel, choć z racji tego, że okna znajdowały się dość wysoko, nie było mowy o zachowaniu dyskrecji.

Zdarzało się jednak, że w ramach kary zabraniano nie tylko odwiedzin, ale również wyjścia na dziedziniec i samodzielnego przygotowania posiłków. Decyzję o tym podejmował osobiście Czengery, a działo się tak, gdy z jakiegoś powodu wpadał w zły humor, najczęściej - jak wspominał Bolesław Anc - poturbowany gdzieś przez Chmielińskiego albo Czachowskie$g 0^{51}$. Szczęśliwie dla więźniów, ale niefortunnie dla powstania, tego typu przypadki nie zdarzały się zbyt często.

Forma przesłuchania więźnia, zwłaszcza dla tych, którzy w pamięci mają opisy przesłuchań z lat II wojny światowej i czasów stalinowskich, może wydać się również szokująca. J. Ożegalski pisał, że gdy trafił przed oblicze komisji śledczej, najpierw została wydana ordynansowi dyspozycja o przyniesieniu więźniowi śniadania. Podczas przesłuchania oficerowie częstowali go winem i cygarami. Trudno powiedzieć, czy stało się tak dlatego, że wielu oficerów stacjonujących w Kielcach jednostek było Polakami, czy raczej - jak pisał Ożegalski - byli po prostu Europejczykami i dżentelmenami. Niewątpliwie jednak na takie, a nie inne traktowanie więźnia wpłynął fakt, iż zarówno przesłuchiwany, jak i przesłuchujący byli szlachcicami, a swoiste poczucie solidarności stanowej równoważyło antagonizmy narodowościowe. Nie należy zatem sądzić, że przesłuchania więźniów pochodzących z niższych warstw społecznych wyglądały podobnie. Zdarzało się również, że w użyciu były knuty i kozackie nahajki. Tak było $\mathrm{m}$. in. w przypadku Tadeusza Cieszyńskiego, którego Czengery kazał jednemu z żołnierzy wziąć na barana, a dwóm innym okładać go nahajami. Po tym przedstawieniu kazał jednak puścić go wolno ${ }^{52}$.

Chociaż pobyt w kieleckim więzieniu był dla większości więźniów traumatycznym doświadczeniem, to jednak dla niejednego z osadzonych lepiej było, aby śledztwo w jego sprawie nie wyszło poza Kielce. Ludomirowi Grzybowskiemu nie szczędzono np. w więzieniu upokorzeń, ale przecież w końcu wypuszczono go na wolność, zmuszając jedynie przedtem do złożenia w kieleckiej katedrze przysięgi na wierność carowi. Wprawdzie po kilku tygodniach został ponownie aresztowany i przesłuchiwany w tzw. sprawie organizacji cywilnej powiatu kieleckiego, ale po

\footnotetext{
${ }^{50}$ J. I. Ożegalski, op. cit., s. 142.

${ }^{51}$ Ibidem.

${ }^{52}$ Ibidem, s. 74.
} 
kilku tygodniach prawie wszystkich zwolniono, ograniczając się jedynie do nałożenia na każdego z aresztowanych kilkusetrublowej kontrybucji ${ }^{53}$. Zupełnie inaczej wyglądało śledztwo w sprawie organizacji cywilnej powiatu stopnickiego, którą z jakichś powodów osobiście zainteresował się Fiodor Berg i do przeprowadzenia śledztwa przysłał z Warszawy pułkownika Hatzwelda ${ }^{54}$. Śledztwo prowadzono w więzieniu w Chęcinach, a w jego trakcie więźniów bito, głodzono, pozbawiano snu.

Więźniowie chorzy albo ranni, po wydaniu opinii przez więziennego lekarza, kierowani byli do kieleckiego szpitala św. Aleksandra ${ }^{55}$. Krzysztof Urbański pisał, iż w czasie powstania styczniowego wielu więźniom politycznym udało się wydostać na wolność po przeniesieniu do szpitala ${ }^{56}$. Można mieć co do tego wątpliwości, gdyż z materiału źródłowego wynika, że były zaledwie dwa takie przypadki, a później wydanie zgody na przeniesienie do szpitala Czengery uzależniał od złożenia przez obywateli miasta poręczenia, iż przeniesiony do szpitala nie ucieknie i stawi się na każde polecenie władzy wojskowej57.

Analizując księgi stanu cywilnego, Engelbert Fajkosz ustalił, że spośród powstańców styczniowych, którzy trafili do kieleckiego więzienia, zmarło 66, ale o przyczynach zgonów informacji nie posiadamy ${ }^{58}$. Można się jedynie domyślać, że owa wysoka śmiertelność wynikała z faktu, iż wielu z nich często ciężko rannych trafiło do Kielc wprost z pól bitewnych. Nie posiadamy bowiem informacji o tym, aby w czasie powstania styczniowego w więzieniu miała miejsce jakaś epidemia skutkująca falą zgonów wśród więźniów, jednak niewątpliwie sytuacja sanitarna, choćby w związku z zagęszczeniem, była trudna.

Nie sposób jednak nie odnieść wrażenia, że los powstańców trafiających do kieleckiego więzienia był nieco lepszy od tego, jaki stał się udziałem tych, którzy mieli nieszczęście trafić do innych więzień. W Kielcach wykonano tylko jeden wyrok śmierci, a w materiale źródłowym brak informacji o fizycznym znęcaniu się nad osadzonymi w celu wydobycia zeznań. Nie szczędzono im wprawdzie kpin i słownych upokorzeń, w czym celował zwłaszcza generał Czengery, ale wydaje się, że szansa na uwolnienie była tu większa niż gdzie indziej. Należy w tym miejscu jednak zastrzec, że zasadniczo nie dotyczyło to powstańców schwytanych z bronią

\footnotetext{
${ }^{53}$ L. Grzybowski, op. cit., s. 142-143.

${ }^{54}$ Grzybowski o tym ostatnim pisał: „Szelma od szubienicy oderwany”, ibidem, s. 143.

${ }^{55}$ APK, Naczelnik Wojenny Powiatu Kieleckiego, sygn. 39, k. 17, 19.

${ }^{56}$ K. Urbański, Kielce w okresie powstania styczniowego, Kielce 1996, s. 96-98.

${ }^{57}$ APK, Naczelnik Wojenny Powiatu Kieleckiego, sygn. 39, k. 18.

${ }^{58}$ Uwzględniono tu również więźniów zmarłych w szpitalu. E. Fajkosz, Powstanie styczniowe w świetle ksiąg stanu cywilnego, „Rocznik Świętokrzyski” 1971, t. 2, s. 147.
} 
w ręku. Tych los był przesądzony. Nawet Czengery zdawał sobie sprawę, że zwalnianie takich osób prędzej czy później skończyłoby się donosami, utratą zaufania zwierzchników i dymisja, a tego nie mogły wynagrodzić żadne łapówki.

Na zakończenie trzeba jeszcze raz podkreślić, że zaprezentowany obraz tego, co działo się $\mathrm{w}$ kieleckim więzieniu podczas powstania styczniowego, trudno uznać za pełny. Nie pozwalają na to zarówno znikomy stopień zachowania materiału archiwalnego, jak i stosunkowo niewielka liczba relacji "pensjonariuszy” tego zakładu. Wprawdzie te ostatnie należy uznać za wysoce wiarygodne, ale poza tym, że jest ich niewiele, to autorami wszystkich są osoby pochodzące z wyższych warstw społecznych. A to, jak już wspomniano, przekładało się na lepsze traktowanie więźniów. Samo pochodzenie jednak często nie wystarczało. Równie ważne, a często i ważniejsze, były pieniądze, za które można było nie tylko poprawić swój byt w więzieniu, ale niejednokrotnie kupić wolność.

Powyższe rozważania pozwalają również na stwierdzenie, że w gorących dniach powstania styczniowego trudno mówić o jednym systemie więziennictwa w Królestwie Polskim. Wszelkie przedpowstaniowe rozporządzenia i dyrektywy w tym zakresie pozostawały często martwą literą. Sytuacja w poszczególnych więzieniach zależała w dużej mierze od lokalnych warunków, a przede wszystkim od ludzi, którzy nagle otrzymali wielką władzę - naczelników wojennych. Położenie uwięzionych często zależało właśnie od ich postawy, a czasami po prostu złego lub dobrego humoru. Stąd też nawet relacje $\mathrm{z}$ tego samego więzienia mogą znacznie się od siebie różnić.

Opinie o kieleckim „kacyku” generale Czengerym są - jak już wspomniałem - raczej pochlebne. J. Siwiński napisał wręcz, że Człowiek ten [...] byt dla nas opatrznościowym. Gdyby na tem stanowisku byt jaki Niemiec, lub jaki inny satrapa! $O$, to do ksieggi martyrologii polskiej przybyłoby sporo kart! ${ }^{59}$ Najlepiej jednak chyba scharakteryzował go J. Ożegalski, pisząc: Byt to wielki frant $i$ komediant. Wyrobiwszy sobie opinię srogiego, mógł potem za grube łapówki uwalniać najciężej obwinionych, bez żadnej odpowiedzialności przed wyższymi władzami. Nie omieszkat też robić tego ${ }^{60}$. Oczywiście na tego typu łaskę liczyć mogły jedynie osoby zamożne. Ogólnie więc należy stwierdzić, że nawet będąc oskarżonym o to samo polityczne przestępstwo, lepiej było być bogatym ziemianinem niż biednym chłopem.

${ }^{59}$ J. Siwiński, op. cit., s. 15.

${ }^{60}$ J. I. Ożegalski, op. cit., s. 146. 


\section{BIBLIOGRAFIA:}

Berg M., Zapiski o polskich spiskach i powstaniach, cz. VI, Warszawa 1906.

Caban W., Stużba rekrutów z Królestwa Polskiego w armii carskiej w latach 1832-1873, Warszawa 2001.

Caban W., Z dziejów powstania styczniowego w rejonie Gór Świętokrzyskich, Warszawa-Kraków 1989.

Fajkosz E., Powstanie styczniowe w świetle ksiag stanu cywilnego, „Rocznik Świętokrzyski” 1971, t. 2, s. 123-156.

Janeczek Z., Terror i przemoc w relacjach śląskiej prasy na przykładzie polskiego powstania 1863 roku, „Siemianowicki Rocznik Muzealny” 2010, nr 9, s. 15-77.

Stefański Ł., Więzienie w Kielcach w latach 1826-1918, Kielce 2010 (na prawach rękopisu).

Urbański K., Kielce w okresie powstania styczniowego, Kielce 1996.

Максутов В. П., История 25-го пехотного Смоленского полка за два века его существования (1700-1900), С.-Петербург 1901.

Русский Биографический Словарь, t. 22, С.-Петербург 1905.

\section{ABSTRACT:}

During the January Uprising in Kielce region fierce fighting took place. Therefore prison in Kielce, a provincial prison in poviat has become one of the most important places of imprisonment in the Polish Kingdom. In this prison were collected political prisoners from across the southern part of the government of Radom. This text is an attempt to present - on the basis of archival documents and the memories of prisoners - the conditions prevailing at that time in Kielce prison and the impact that the plight of the prisoners have people supervising their stay in prison, especially military chief General Onufry Czengery.

Key words: Kielce, prison, the January uprising, the Kingdom Polish.

\section{NOTA O AUTORZE:}

Jacek Legieć - doktor habilitowany nauk humanistycznych, adiunkt w Instytucie Historii Uniwersytetu Jana Kochanowskiego w Kielcach. Absolwent Uniwersytetu Łódzkiego (1994). Rozprawę doktorską pt. Armia Ukraińskiej Republiki Ludowej w kampanii polsko-bolszewickiej 1920 r., której promotorem był Wojciech Materski, obronił w 1999 r. na Wydziale Filozoficzno-Historycznym Uniwersytetu Łódzkiego. Stopień naukowy doktora habilitowanego uzyskał w roku 2014 na Uniwersytecie Jana Kochanowskiego w Kielcach w oparciu o pracę Służba rekrutów z Królestwa Polskiego w armii rosyjskiej w latach 1874-1913. E-mail: jleg@poczta.onet.pl 